\title{
Novel and Highly Specific Monoclonal Antibody to Acidovorax citrulli and Development of ELISA-Based Detection in Cucurbit Leaves and Seed
}

\begin{abstract}
Orawan Himananto, Center for Agricultural Biotechnology, Kasetsart University, Kamphaeng Saen Campus, Nakhon Pathom 73140, Thailand; Center of Excellence on Agricultural Biotechnology (AG-BIO/PERDO-CHE), Bangkok 10900, Thailand; and National Center for Genetic Engineering and Biotechnology, National Science and Technology Development Agency, Pathumthani 12120, Thailand; Petcharat Thummabenjapone, Center of Excellence on Agricultural Biotechnology (AG-BIO/PERDO-CHE); and Agricultural Biotechnology Research Center for Sustainable Economy, Khon Kaen University, Khon Kaen 40002, Thailand; Plearnpis Luxananil and Mallika Kumpoosiri, National Center for Genetic Engineering and Biotechnology, National Science and Technology Development Agency, Pathumthani 12120, Thailand; Ratchanee Hongprayoon and Wichai Kositratana, Center for Agricultural Biotechnology, Kasetsart University, Kamphaeng Saen Campus, Nakhon Pathom 73140, Thailand; Center of Excellence on Agricultural Biotechnology (AG-BIO/PERDO-CHE), Bangkok 10900, Thailand; and Department of Plant Pathology, Faculty of Agriculture at Kamphaeng Saen, Kasetsart University; and Oraprapai Gajanandana, National Center for Genetic Engineering and Biotechnology, National Science and Technology Development Agency, Pathumthani 12120, Thailand
\end{abstract}

\begin{abstract}
Himananto, O., Thummabenjapone, P., Luxananil, P., Kumpoosiri, M., Hongprayoon, R., Kositratana, W., and Gajanandana, O. 2011. Novel and highly specific monoclonal antibody to Acidovorax citrulli and development of ELISA-based detection in cucurbit leaves and seed. Plant Dis. 95:1172-1178.

A novel monoclonal antibody (MAb) specific to the seedborne bacterium Acidovorax citrulli was produced. MAb 11E5 reacted specifically with 19 strains of $A$. citrulli but not with three closely related bacteria in the family Comamonadaceae (i.e., A. facilis, Comamonas acidovorans, and C. testosteroni) and another seven phytopathogenic bacteria. Moreover, this MAb detected a strain of A. citrulli that was not detected by a commercial enzyme-linked immunosorbent assay (ELISA)-based kit and a commercial immunochromatographic strip test. In Western blot analysis, MAb 11E5 reacted with an A. citrulli

develop two sandwich ELISA systems: MAb captured-sandwich ELISA (MC-sELISA) and polyclonal antibody captured-sandwich ELISA (PC-sELISA). MC-sELISA was 10 times more sensitive than PC-sELISA for detection of $A$. citrulli in cucurbit leaf and seed extracts. The detection limit of the MC-sELISA was $5 \times 10^{4} \mathrm{CFU} / \mathrm{ml}$. Detection of $A$. citrulli in naturally infected cucurbit leaves, fruit, and seed was also feasible using MC-sELISA. The newly established MCsELISA provides another alternative for specific detection of A. citrulli in cucurbits and can be applied for routine field inspection.
\end{abstract} protein of a molecular mass $>170 \mathrm{kDa}$. MAb 11E5 was employed to
Acidovorax citrulli (originally Pseudomonas pseudoalcaligenes subsp. citrulli and subsequently changed to A. avenae subsp. citrulli) $(15,16,23)$ is a gram-negative bacterium that causes bacterial fruit blotch (BFB) of cucurbits, resulting in severe losses in cucurbit production worldwide. This bacterium causes serious concerns for the vegetable seed industry because it is naturally borne and transmitted by seed $(2,7,13)$. BFB can be devastating for seed producers because it can result in $100 \%$ yield reduction (9). In Thailand, cucurbit seed, such as watermelon, cantaloupe, cucumber, gourd, squash, and pumpkin seed, account for 30\% (approximately U.S.\$29 million) of the total seed exported (approximately U.S.\$98 million) in 2009 (The Office of Agricultural Regulation, Department of Agriculture Thailand, Retrieved from, http:// www.oae.go.th/ewtadmin/ewt/oae_web/ewt_news.php?nid=8115\& filename=index). Phytosanitary certification is required for cucurbit seed export. Field inspection prior to harvest or seed testing is required depending on regulation of each country. Standard methods for seed testing to detect A. citrulli are the seedling grow-out assays (SGO) and bacterial isolation on semiselective media, which are laborious and time consuming and require large areas of greenhouse space. To alleviate this problem, most of the previous studies have focused on developing new methods for seed testing such as immuno-

Corresponding author: O. Gajanandana, E-mail: oraprapai@biotec.or.th

Accepted for publication 15 May 2011.

doi:10.1094/PDIS-12-10-0889

(C) 2011 The American Phytopathological Society magnetic separation polymerase chain reaction (PCR) and immunocapture-PCR $(19,21,22)$.

Nevertheless, a majority of importing countries, such as China, France, Japan, Netherlands, Israel, and the United States, requires field inspection prior to harvest (S. Kessank, Plant Protection Research and Development Office, Department of Agriculture, Thailand, personal communication). For field inspection, general methods for detection of suspicious plant samples are the enzymelinked immunosorbent assay (ELISA) or PCR methods for initial screening. Positive samples are then confirmed with bacterial isolation on semiselective media (1). However, ELISA is the more widely used technique for routine field inspection because it is simple, cheap, and robust without a need of expensive equipment. Moreover, ELISA does not require pathogen isolation. For immunological assays, specificity and sensitivity depend on the characteristics of antibodies; therefore, highly specific antibodies are critical for this type of assay.

In the case of $A$. citrulli, available rabbit polyclonal antibodies (PAbs) yield false-positive results because they also react with closely related bacteria such as other Acidovorax spp. and Comamonas acidovorans $(18,21)$. Monoclonal antibodies (MAbs) offer several advantages over conventional polyclonal antiserum such as specificity for a single epitope, consistent quality, and unlimited quantity of antibodies. Although a MAb against $A$. citrulli is commercially employed in an ELISA test kit for A. citrulli detection (Agdia), its production and characterization has never been reported. Therefore, this study reports the first detailed production and characterization of a highly specific MAb against A. citrulli and the establishment of the MAb captured-sandwich (MC-s)ELISA for direct detection of this pathogen in cucurbit leaf, fruit and seed samples. 


\section{Materials and Methods}

Bacterial strains. Bacterial strains used in this study are shown in Table 1. Confirmation of Acidovorax citrulli strains was performed using carbon-source metabolic fingerprinting (Biolog system) according to manufacturer's instructions (Biolog Inc., Hayward, CA) and pathogenicity assays on various cucurbit seedlings such as watermelon (Citrullus lanatus), melon (Cucumis melo), and cucumber (C. sativas) (6). All strains were also tested by PCR using primers specific to the 16S rRNA gene of A. citrulli (20). All bacteria were preserved in Nutrient Broth (NB), (Difco, France) with $15 \%$ glycerol at $-80^{\circ} \mathrm{C}$.

To prepare the bacterial cell suspensions, bacteria were cultured on NB with $1.5 \%$ Bacto agar (Difco) and incubated at $28^{\circ} \mathrm{C}$ for 48 h. A single colony was selected and inoculated into $50 \mathrm{ml}$ of $\mathrm{NB}$. The cultures were incubated at $28^{\circ} \mathrm{C}$ for $18 \mathrm{~h}$, with shaking at 200 rpm. The optical density at a wavelength of $600 \mathrm{~nm}\left(\mathrm{OD}_{600}\right)$ was measured using a spectrophotometer (spectro UV-VIS RS; Labomed Inc.). The total numbers of bacteria were calculated based on a conventional plate count method $\left(\mathrm{OD}_{600}\right.$ of 1.0 corresponding to approximately $\left.1 \times 10^{9} \mathrm{CFU} / \mathrm{ml}\right)$. The bacteria were harvested after centrifugation at 5,000 rpm for $10 \mathrm{~min}$ (Sorvall). The cell pellets were washed twice with $5 \mathrm{ml}$ of $0.1 \mathrm{M}$ phosphatebuffered saline (PBS; $1.5 \mathrm{mM} \mathrm{KH} \mathrm{PO}_{4}, 137 \mathrm{mM} \mathrm{NaCl}, 20 \mathrm{mM}$ $\mathrm{Na}_{2} \mathrm{HPO}_{4}$, and $2.7 \mathrm{mM} \mathrm{KCl}[\mathrm{pH} \mathrm{7.2])} \mathrm{and} \mathrm{resuspended} \mathrm{in} 5 \mathrm{ml}$ of PBS to obtain a final concentration of $1 \times 10^{10} \mathrm{CFU} / \mathrm{ml}$.

Antigen preparation. The A. citrulli strain KK9 (Ac KK9) was isolated from symptomatic watermelon fruit collected in Khon
Kaen province (Thailand) and used as an antigen for MAb production. A cell suspension of Ac KK9 was cultured as described above and sonicated using ultrasonic sonicator (Sonic Vibra cell) at 35\% amplitude for 5 min on ice with 10-s intervals. Protein concentration was determined by the Bradford method (3) and adjusted to $0.5 \mathrm{mg} / \mathrm{ml}$. The antigens were stored at $-20^{\circ} \mathrm{C}$ until use.

MAb production. The hybridoma production protocol used was modified from the method developed by Oi and Herzenberg (12). Six-week-old BALB/c mice were injected intraperitoneally (i.p.) with $100 \mu \mathrm{g}$ of sonicated cell suspension of A. citrulli (approximately $\left.1.8 \times 10^{8} \mathrm{CFU}\right)$. Three immunizations were performed at 2 week intervals. Serum from each immunized mouse obtained 7 days after each immunization was tested for antibodies against cell suspension of $A$. citrulli using plate-trapped antigen (PTA)-ELISA as described below. The mouse with the highest antibody titer was challenged i.p. with $120 \mu \mathrm{g}$ of the antigen and sacrificed 3 days later for hybridoma preparation. Isolated mouse splenocytes were fused with P3X63-Ag8.653 mouse myeloma cells (spleen cells/myeloma cells ratio of 5:1) in the presence of $50 \%$ (wt/vol) polyethylene glycol (1450 Hybri Max; Sigma-Aldrich, St. Louis). Hybridoma cells were selected by culturing in hypoxanthine aminopterin thymidine (HAT) medium, which composed of RPMI 1640 medium (Invitrogen), 20\% (vol/vol) fetal bovine serum (PAA Laboratories, Austria), 1× HAT supplement (Sigma-Aldrich), and 10\% (vol/vol) BM-Condimed H1 (Hybridoma Cloning Supplement, Roche). Cultures were propagated and screened for production of antibodies to $A$. citrulli using PTA-ELISA. Cross reactivity of antibodies with Comamonas acidovorans and nonspecific bind-

Table 1. Specificity of monoclonal antibody (MAb) 11E5 and MAb 10B2 against Acidovorax citrulli and other bacterial strains using plate-trapped antigen enzyme-linked immunosorbent assay (PTA-ELISA), compared with those of commercial ELISA test kit and commercial immunochromatographic strip test ${ }^{\mathrm{a}}$

\begin{tabular}{|c|c|c|c|c|c|c|}
\hline \multirow[b]{2}{*}{ Bacterial strains } & \multirow[b]{2}{*}{ Host } & \multirow[b]{2}{*}{ Source $^{b}$} & \multicolumn{2}{|c|}{$\begin{array}{c}\text { PTA-ELISA activity } \\
\left(A_{405}\right)\end{array}$} & \multicolumn{2}{|c|}{$\begin{array}{c}\text { Commercial } \\
\text { test kit }\end{array}$} \\
\hline & & & MAb 11E5 & MAb 10B2 & ELISA & QuickStix \\
\hline \multicolumn{7}{|l|}{ Acidovorax citrulli } \\
\hline Ac-KK9 & Watermelon & Khon Kaen & $1.68(+)$ & $2.61(+)$ & $3.19(+)$ & + \\
\hline Ac-WM-MK 5/2 & Watermelon & Mahasarakham & $2.78(+)$ & $3.19(+)$ & $3.20(+)$ & + \\
\hline Ac-WM-MK 4/2 & Watermelon & Mahasarakham & $2.57(+)$ & $3.31(+)$ & $3.32(+)$ & + \\
\hline Ac-WM-MK 4/1 & Watermelon & Mahasarakham & $2.82(+)$ & $3.25(+)$ & $3.24(+)$ & + \\
\hline Ac-WM-MK 5/1 & Watermelon & Mahasarakham & $2.56(+)$ & $3.39(+)$ & $3.24(+)$ & + \\
\hline Ac-WM-NB 4/2 & Watermelon & Nongboulampoo & $2.41(+)$ & $3.14(+)$ & $3.23(+)$ & + \\
\hline Ac-DOAC 4- 1364 & Melon & DOA & $2.59(+)$ & $3.36(+)$ & $2.69(+)$ & + \\
\hline Ac-DOAC 4- 1194 & Watermelon & DOA & $1.81(+)$ & $2.56(+)$ & $2.77(+)$ & + \\
\hline Ac-LS & Cantaloupe & DPAN & $2.03(+)$ & $3.09(+)$ & $3.09(+)$ & + \\
\hline Ac-WS & Watermelon & DPAN & $2.11(+)$ & $3.09(+)$ & $3.41(+)$ & + \\
\hline $\mathrm{Ac}-\mathrm{CU}$ & Cucumber & DPAN & $1.98(+)$ & $3.12(+)$ & $3.11(+)$ & + \\
\hline Ac-WM007/1 ${ }^{\mathrm{c}}$ & Bottle gourd & Imported seed & $1.18(+)$ & $3.02(+)$ & $3.23(+)$ & + \\
\hline Ac-WM 015/2c & Squash & Imported seed & $2.66(+)$ & $3.35(+)$ & $3.30(+)$ & + \\
\hline Ac-WM006/1 ${ }^{c}$ & Bottle gourd & Imported seed & $2.76(+)$ & $3.34(+)$ & $3.04(+)$ & + \\
\hline Ac-WM006/2c & Bottle gourd & Imported seed & $1.34(+)$ & $3.09(+)$ & $3.23(+)$ & + \\
\hline Ac-WM 015/1 & Squash & Imported seed & $3.04(+)$ & $3.32(+)$ & $3.22(+)$ & + \\
\hline Ac-WM007/2c & Bottle gourd & Imported seed & $2.71(+)$ & $3.35(+)$ & $3.15(+)$ & + \\
\hline Ac-SQ type $A^{c}$ & Squash & Imported seed & $2.11(+)$ & $0.10(-)$ & $3.23(+)$ & + \\
\hline Ac-SQ type $B^{c}$ & Squash & Imported seed & $2.04(+)$ & $0.09(-)$ & $0.10(-)$ & - \\
\hline A. facilis & Watermelon & DPAK & $0.11(-)$ & $0.11(-)$ & $0.12(-)$ & - \\
\hline Burkhoderia plantarii & Watermelon & DPAK & $0.11(-)$ & $0.09(-)$ & $0.08(-)$ & - \\
\hline Comamonas acidovorans & Watermelon & DPAK & $0.16(-)$ & $3.47(+)$ & $0.10(-)$ & - \\
\hline C. testosteroni & Watermelon & DPAK & $0.15(-)$ & $2.02(+)$ & $0.11(-)$ & - \\
\hline Pectobacterium carotovorum subsp. carotovorum & Chinese cabbage & DPAK & $0.11(-)$ & $0.07(-)$ & $0.11(-)$ & - \\
\hline Fluorescent Pseudomonas spp. & Cucurbits & DPAK & $0.09(-)$ & $0.08(-)$ & $0.10(-)$ & - \\
\hline Pantoea ananus & Tomato & DPAK & $0.11(-)$ & $0.07(-)$ & $0.12(-)$ & - \\
\hline Ralstonia solanacearum & Tomato & DPAK & $0.12(-)$ & $0.08(-)$ & $0.13(-)$ & - \\
\hline Xanthomonas campestris pv. vesicatoria & Tomato & DPAK & $0.08(-)$ & $0.07(-)$ & $0.12(-)$ & - \\
\hline Carbonate buffer (negative control) & - & - & $0.09(-)$ & $0.08(-)$ & $0.09(-)$ & - \\
\hline
\end{tabular}

${ }^{a}$ PTA-ELISA and commercial ELISA kit (Agdia) were performed in three replicates for each sample. A sample was considered positive when an absorbance at $405 \mathrm{~nm}\left(A_{405}\right)$ value was higher than twice the value of carbonate buffer (negative control). Bacteria were also tested with immunochromatographic strip test, QuickStix (Envirologix) following the manufacturer's instruction.

${ }^{\mathrm{b}}$ Sources from Thailand, including DOA: Department of Agriculture, Ministry of Agriculture and Cooperatives, Thailand; DPAK: Department of Plant Sciences and Agricultural Resources, Khon Kaen University, Khon Kaen 40002, Thailand; and DPAN: Department of Plant Pathology, Kasetsart University, Kamphaeng Saen Campus, Nakhon Pathom 73140, Thailand.

${ }^{c}$ Bacterial isolate obtained from seedling grow-out test for bacterial fruit blotch pathogen. All of the tested seedlings were sterilized by autoclave after examination. 
ing to the plate (no antigen) were also evaluated in this assay. Hybridoma cultures that produced antibodies to A. citrulli were cloned by the limiting dilution method to produce monoclonal cultures of antibody-producing hybridoma cells (14).

Characterization of MAbs. Immunoglobulin types were identified with the Mouse MonoAb ID Kit (Zymed; Invitrogen). Specificity of MAbs against A. citrulli and other bacteria was determined by PTA-ELISA and Western blot analysis as described below. To compare between our MAb and MAbs in commercial tests, ELISA kit (Agdia) and immunochromatographic strip test (Envirologix) were also evaluated for specificity against these bacteria.

PTA-ELISA. Ninety-six-well microtiter plates (Corning Inc.) were coated overnight at $4^{\circ} \mathrm{C}$ with $100 \mu \mathrm{l}$ of $10^{8} \mathrm{CFU} / \mathrm{ml}$ of a bacterial cell suspension diluted in carbonate buffer $(14 \mathrm{mM}$ $\mathrm{Na}_{2} \mathrm{CO}_{3}$ and $35 \mathrm{mM} \mathrm{NaHCO} 3, \mathrm{pH} 9.6$ ). The plates were washed four times with $400 \mu \mathrm{l}$ of PBS $+0.05 \%$ Tween 20, $\mathrm{pH} 7.2$ (PBST) before being blocked with $100 \mu \mathrm{l}$ of $2 \%$ bovine serum albumin (BSA; Sigma-Aldrich) in PBST for $1 \mathrm{~h}$ at $25^{\circ} \mathrm{C}$. Subsequently, plates were washed as described above. Hybridoma culture supernatant, cultured medium containing antibodies secreted from hybridoma cell $(100 \mu \mathrm{l})$, was then added and incubated for $1 \mathrm{~h}$ at $25^{\circ} \mathrm{C}$. Each plate was washed with PBST before $100 \mu \mathrm{l}$ of 1/2,000 goat anti-mouse immunoglobulins conjugated with alkaline phosphatase (Sigma-Aldrich) diluted in $0.5 \%$ BSA in PBST were added and incubated for $1 \mathrm{~h}$ at $25^{\circ} \mathrm{C}$. After washing, $100 \mu \mathrm{l}$ of a substrate solution for alkaline phosphatase, $p$-nitrophenyl phosphate (pNPP, Zymed; Invitrogen), was added and incubated for $1 \mathrm{~h}$ at $25^{\circ} \mathrm{C}$. The absorbance at $405 \mathrm{~nm}$ was measured using an automated microplate reader (VersaMax). A result was considered positive when the absorbance was at least twice that of the negative controls.

Western blot analysis. Proteins from a whole-cell suspension (1 $\times 10^{8} \mathrm{CFU}$ ) of $A$. citrulli and C. acidovorans were subjected to the discontinuous sodium dodecyl sulfate polyacrylamide gel electrophoresis using a 5\% stacking gel and 10\% separating gel under reducing conditions (8). Protein molecular weight markers (number SM0671; Fermentas, UK) were included in each gel. Proteins were transferred to a nitrocellulose membrane (BioTrace; Pall Corporation) using a semidry blotting apparatus (Trans-Blot Semi-Dry Electrophoretic Transfer Cell; Bio-Rad). The membranes were soaked in $5 \mathrm{ml}$ of Tris-buffered saline plus Tween 20 (TBST; 10 $\mathrm{mM}$ Tris [pH 8], $150 \mathrm{mM} \mathrm{NaCl}$, and $0.05 \%$ Tween 20) for $10 \mathrm{~min}$ and blocked with $5 \mathrm{ml}$ of $4 \%$ BSA in TBST for $1 \mathrm{~h}$. The nitrocellulose membranes were then incubated with $5 \mathrm{ml}$ of mouse MAb against $A$. citrulli for $1 \mathrm{~h}$. After washing with TBST three times for 10 min each, detection was carried out using alkaline phosphatase conjugated goat anti-mouse immunoglobulin $\mathrm{G}$ (IgG) $(\mathrm{H}+\mathrm{L})$ (Sigma-Aldrich) for $1 \mathrm{~h}$. The membranes were washed as above and incubated for 2 to $3 \mathrm{~min}$ in the substrate solution (NBT/BCIP Kit; Zymed). The color development was stopped by immersing the membrane in distilled water. The membrane was air dried. Molecular weight of each protein band was compared with standard molecular weight markers.

Development of sandwich ELISAs for detection of $A$. citrulli in plant samples. Two systems of sandwich (s)ELISAs were developed. First, MC-sELISA used MAb 11E5 as capture antibodies and rabbit PAbs against a membrane protein complex of $A$. citrulli (anti-Ac MPC rPAb; purchased from the Department of Plant Pathology, Faculty of Agriculture, Kasetsart University, Kamphaeng Saen Campus, Thailand) as detecting antibodies. Second, PAb captured-sandwich ELISA (PC-sELISA) used anti-Ac MPC rPAb as capture antibodies and MAb 11E5 as detecting antibodies.

For MC-sELISA, 96-well microtiter plates were coated overnight at $4^{\circ} \mathrm{C}$ or for $2 \mathrm{~h}$ at $25^{\circ} \mathrm{C}$ with $100 \mu$ of MAb $11 \mathrm{E} 5$ at 2 $\mu \mathrm{g} / \mathrm{ml}$ diluted in carbonate buffer. The plates were washed four times with $400 \mu \mathrm{l}$ of PBST. Bacteria $(100 \mu \mathrm{l})$ with 10 -fold serial dilution $\left(0\right.$ to $\left.10^{8} \mathrm{CFU} / \mathrm{ml}\right)$ in an extraction buffer (PVPBST ${ }^{+}: 0.06$ $\mathrm{M} \mathrm{Na}_{2} \mathrm{SO}_{3}, 2 \%$ [wt/vol] polyvinylpyrrolidone 40, egg albumin at 2 g/liter, and $2 \%$ Tween 20 in PBS) were added to the wells and incubated for $1 \mathrm{~h}$ at $25^{\circ} \mathrm{C}$. Each plate was washed with PBST as described above before $100 \mu$ of $1 / 4000$ anti-Ac MPC rPAb diluted in $0.5 \%$ BSA in PBST was added and incubated for $1 \mathrm{~h}$ at $25^{\circ} \mathrm{C}$. Each plate was then rewashed. Goat anti-rabbit immunoglobulins conjugated with alkaline phosphatase (Sigma-Aldrich) diluted $1 / 10,000$ in $0.5 \%$ BSA in PBST $(100 \mu \mathrm{l} /$ well $)$ were added and incubated for $1 \mathrm{~h}$ at $25^{\circ} \mathrm{C}$. The chromogenic signal was obtained as described above. For PC-sELISA, the protocol was similar to MC-sELISA except that anti-Ac MPC rPAb was used as the capture antibody and MAb 11E5 was used as the secondary antibody. Goat anti-mouse immunoglobulin conjugated with alkaline phosphatase was used as the tertiary antibody.

To optimize these two sELISAs, three extraction buffers (PVPBST ${ }^{+}$, Tris- $\mathrm{Na}_{2} \mathrm{SO}_{3}$, and PBST) were compared in A. citrulli detection. Buffer PVPBST ${ }^{+}$was composed of $0.06 \mathrm{M} \mathrm{Na}_{2} \mathrm{SO}_{3}, 2 \%$ (wt/vol) polyvinylpyrrolidone 40 , egg albumin at $2 \mathrm{~g} /$ liter, and $2 \%$ Tween 20 in PBS. Buffer Tris- $\mathrm{Na}_{2} \mathrm{SO}_{3}$ was composed of $0.05 \mathrm{M}$ Tris- $\mathrm{HCl}$ and $0.06 \mathrm{M} \mathrm{Na}_{2} \mathrm{SO}_{3}, \mathrm{pH}$ 8.5. Buffer PBST was composed of PBS with $0.05 \%$ Tween 20, $\mathrm{pH}$ 7.4. A. citrulli and other bacteria (fluorescent Pseudomonas spp., Xanthomonas campestris pv. vesicatoria, Pectobacterium carotovorum subsp. carotovorum, and $C$. acidovorans) were individually diluted in an extraction buffer to obtain final concentration of approximately $10^{8} \mathrm{CFU} / \mathrm{ml}$. The bacterial suspensions were assayed by both sELISA procedures as described above.

In order to compare the sensitivity of the two sELISAs, $A$. citrulli cells were spiked into $\mathrm{PVPBST}^{+}$extraction buffer and leaf and seed extracts to obtain final concentrations of 0 to $10^{8} \mathrm{CFU} / \mathrm{ml}$. Leaf extracts were prepared by grinding leaves from healthy plants $\left(20 \%\right.$, wt/vol) in PVPBST $^{+}$extraction buffer. Seed wash was prepared by incubating noninfested watermelon seed ( 100 seeds) in 10 $\mathrm{ml}$ of $\mathrm{PVPBST}^{+}$for $1 \mathrm{~h}$ at approximately $25^{\circ} \mathrm{C}$ with agitation at $200 \mathrm{rpm}$. For seed macerate, noninfested watermelon seed (100 seeds) were crushed in $10 \mathrm{ml}$ of $\mathrm{PVPBST}^{+}$using a homogenizer (Philips, The Netherland). Both seed extracts were passed through two layers of cheesecloth to remove the seed debris and the filtrate was kept for further use. Ac KK9 was cultured and prepared as described above. The Ac KK9 suspension was adjusted to an $\mathrm{OD}_{600}$ of 1.0 (approximately $10^{9} \mathrm{CFU} / \mathrm{ml}$ ). Using this cell suspension, 10fold serial dilutions were made in PVPBST $^{+}$buffer, leaf extracts, seed wash, and seed macerate. Each diluted sample was analyzed by the two ELISA assays along with the commercial ELISA kit (Agdia).

Detection of $A$. citrulli in naturally infected leaf and fruit. The MC-sELISA was applied to test naturally infected leaf and fruit samples. In total, 56 leaf and fruit samples of watermelon and melon showing BFB-like symptoms were collected from 10 production fields in six provinces in Thailand. Leaf extracts were prepared as described above. For the fruit extraction, approximately $5 \mathrm{~g}$ of fruit skin with lesion were ground $(50 \%, \mathrm{wt} / \mathrm{vol})$ in PVPBST $^{+}$extraction buffer. The samples were analyzed by MCsELISA in parallel with a commercial $A$. citrulli ELISA test kit (catalog number SRA 14800; Agdia). Healthy leaf and fruit samples were included in all experiments as negative controls.

Detection of $A$. citrulli in artificially and naturally infested seed. Artificially infested seed were prepared by soaking noninfested watermelon seed $(n=100)$ in $20 \mathrm{ml}$ of $A$. citrulli suspension $\left(10^{8} \mathrm{CFU} / \mathrm{ml}\right)$. The seed suspension was then vacuum infiltrated for $20 \mathrm{~min}$ in a vacuum jar and the seed were allowed to air dry overnight at room temperature (21). Each infested seed contained approximately $10^{6}$ to $10^{7} \mathrm{CFU}$ of $A$. citrulli, determined by bacterial plate count. The infested seed were mixed with noninfested seed to generate different levels of $A$. citrulli contamination (number of infested seed/total number of seed tested): $0 \%(0 / 1,000), 0.1 \%$ $(1 / 1,000), 0.3 \%(3 / 1,000), 1 \%(10 / 1,000)$, and 5\% (50/1,000). Each test was performed in three replicates. Seed extracts (seed wash and seed macerate) were prepared and tested by MC-sELISA as described above. Noninfested seed were used as negative control. For naturally infested seed lots, watermelon and cucumber seed 
lots from 10 production fields in Khon Kaen province (Thailand) were screened for A. citrulli using MC-sELISA. Seed $(n=400)$ from each lot were ground in $40 \mathrm{ml}$ of $\mathrm{PVPBST}^{+}$and prepared as described above. Seed macerate samples were subjected to MCsELISA and the commercial ELISA kit for comparison. The tests were performed in parallel with a modified SGO assay as follows. For SGO, 100 seeds per lot were placed on blotter paper (Hoffman Manufacturing Inc., Albany, OR), saturated with sterile water, and incubated in a closed, transparent plastic box ( 6 by 24 by $33.5 \mathrm{~cm}$ [height by width by length]) (10). Seed were incubated in a transparent plastic box for 14 days under conditions of 28 to $35^{\circ} \mathrm{C}$ and $>90 \%$ relative humidity. During this time, the seedlings were visually evaluated every day for BFB symptoms.

\section{Results}

Production and characterization of MAbs. To produce MAbs specific to A. citrulli, the sonicated cell suspension of $A$. citrulli was used as an immunogen for MAb production. All 630 wells of the fused cells contained hybridoma cells. Culture supernatants from 10 of the 630 cultures strongly reacted with A. citrulli cells coated on the microtiter plates in PTA-ELISA and remained stable after cloning. However, 9 hybridoma clones (1D4, 2C2, 4C11, 6F3, 7F7, 7G10, 9D7, 10B2, and 10F6) of the 10 clones also cross-reacted with $C$. acidovarans. Only one MAb, 11E5, reacted specifically with $A$. citrulli and not with other closely related bacteria. Two hybridoma clones (MAb11E5 and MAb10B2) were selected to represent the two groups of MAbs (specific and nonspecific to A. citrulli) and further characterized.

The specificity of MAbs 11E5 and 10B2 was analyzed against a wide range of bacteria (Table 1) using PTA-ELISA. MAb 11E5 (isotype $\operatorname{IgG}_{1}, \kappa$ light chain) reacted specifically with all 19 strains of $A$. citrulli tested with no cross-reaction to closely related bacteria in the family Comamonadaceae (such as A. facilis, C. acidovorans, and $C$. testosteronii) and other phytopathogenic bacteria (Table 1). MAb 10B2 (isotype $\operatorname{IgG}_{1}, \kappa$ light chain) reacted with only 17 of the 19 strains of $A$. citrulli tested and also cross-reacted with closely related bacteria in the family Comamonadaceae such as C. acidovorans and C. testosteronii. However, MAb 10B2 did not cross-react with other unrelated bacteria (Table 1). Similar results were obtained by the Western blot analysis. MAb 11E5 specifically reacted with $A$. citrulli isolates, yielding a single protein band at molecular weight greater than $170 \mathrm{kDa}$, while MAb 10B2 bound to proteins from $A$. citrulli and C. acidovorans at approximately 43 and $34 \mathrm{kDa}$, respectively (Fig. 1). MAb 11E5 was chosen for further assay development due to its high specificity to A. citrulli. Moreover, MAb 11E5 reacted with all 19 A. citrulli strains tested while the commercial ELISA kit (Agdia) and immunochromatographic strip test (QuickStix; Envirologix) failed to detect one strain (Table 1).

Development of SELISA for detection of $A$. citrulli in plant samples. The MAb 11E5 was used to develop two sELISA proto-
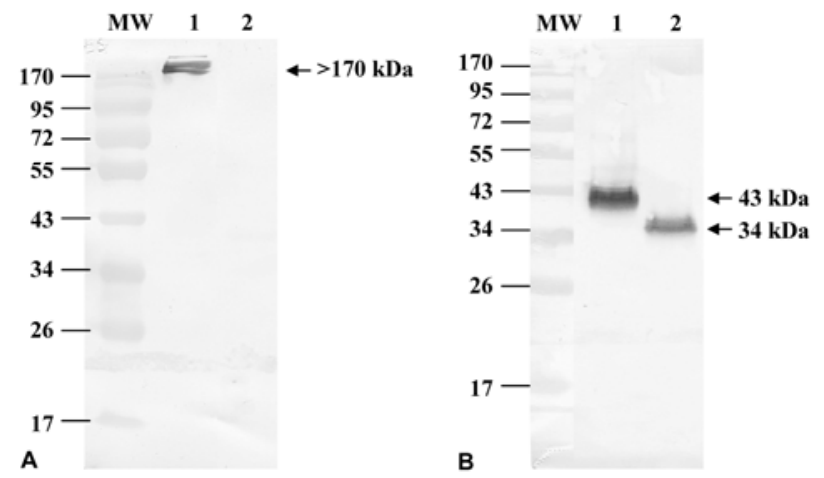

Fig. 1. Western blot analysis of whole-cell suspensions of Acidovorax citrulli (lane 1) and Comamonas acidovorans (lane 2) probed with $\mathbf{A}$, monoclonal antibody (MAb) $11 \mathrm{E} 5$ and B, MAb 10B2. Molecular-weight (MW) standards (Fermentas) are shown in kilodaltons on the left side. cols (MC-sELISA and PC-sELISA) for detection of A. citrulli in plant samples. In order to optimize both ELISA systems, three different extraction buffers (PVPBST ${ }^{+}, \mathrm{Tris}_{2} \mathrm{Na}_{2} \mathrm{SO}_{3}$, and PBST) were compared. A. citrulli and other bacteria, including $X$. campestris pv. vesicatoria, $P$. carotovorum subsp. carotovorum, fluorescent Pseudomonas spp., and C. acidovorans, were spiked into each extraction buffer $\left(10^{8} \mathrm{CFU} / \mathrm{ml}\right)$ and analyzed by both sELISA systems. With the PC-sELISA system, all extraction buffer types gave comparable results without nonspecific reaction with other bacteria (Fig. 2A). For MC-sELISA, nonspecific reaction with other bacteria was found when Tris- $\mathrm{Na}_{2} \mathrm{SO}_{3}$ and PBST were used to dilute the bacteria (Fig. 2B). Specific detection of A. citrulli was obtained when PVPBST $^{+}$was used as an extraction buffer in MC-sELISA (Fig. 2B). Therefore, PVPBST $^{+}$was selected to use as an extraction buffer for further assay development.

After the suitable extraction buffer was selected, the two sELISA systems (MC-sELISA and PC-sELISA) were compared for their sensitivity in detecting $A$. citrulli spiked in buffer, leaf, and seed extracts. From the results, ELISA sensitivity was not affected by the type of sample (seed or leaf) or preparation method (grinding or washing; Fig. 3). MC-sELISA has the same sensitivity in detection of A. citrulli when compared with a commercial ELISA kit (Agdia) (Fig. 3). MC-sELISA was approximately 10-fold more sensitive than the PC-sELISA in detection of A. citrulli in all cases (Fig. 3). The detection limit of MC-sELISA was the same as that of the commercial ELISA kit (Agdia) (approximately $5 \times 10^{4}$ $\mathrm{CFU} / \mathrm{ml}$ ) while lower sensitivity was obtained in PC-sELISA (approximately $5 \times 10^{5} \mathrm{CFU} / \mathrm{ml}$ ). In all subsequent experiments, the MC-sELISA protocol was used.

Detection of $A$. citrulli in naturally infected leaves and fruit. In total, 56 leaf and fruit samples showing BFB-like symptoms were collected from 10 production fields in six provinces in Thailand. MC-sELISA and a commercial ELISA kit were used to assay for A. citrulli in these samples and both methods gave $100 \%$ agreement, with 31 positive and 25 negative results. Healthy leaves and fruit skins gave negative results using MC-sELISA and commercial ELISA kit.
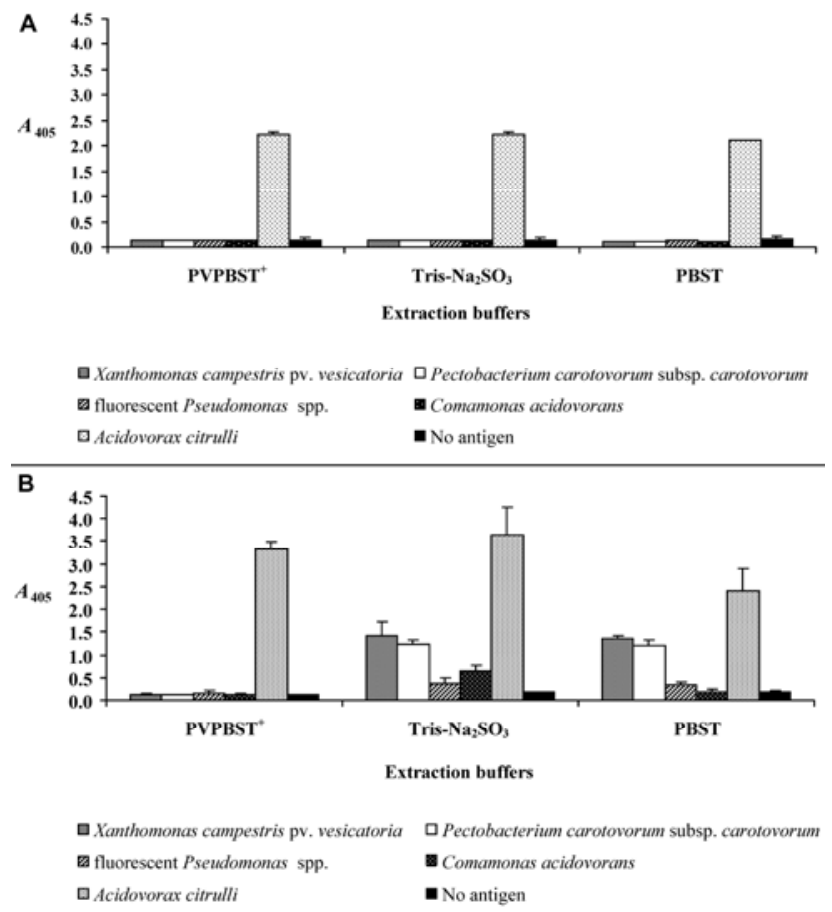

Fig. 2. Comparison of extraction buffers. Bacteria were resuspended in three extraction buffers at the concentration of $10^{8} \mathrm{CFU} / \mathrm{ml}$ and then were analyzed by $\mathbf{A}$, polyclonal antibody captured-sandwich (PC-s) enzyme-linked immunosorbent assay (ELISA) and B, monoclonal antibody captured-sandwich (MC-s)ELISA. PBST = phosphate-buffered saline with Tween 20 and $\mathrm{PVPBST}^{+}=$PBS with polyvinylpyrrolidone $40, \mathrm{Na}_{2} \mathrm{SO}_{3}$, egg albumin, and Tween 20 . 
Detection of $A$. citrulli in artificially and naturally infested seed lots. To evaluate the sensitivity of MC-sELISA and commercial ELISA kit (Agdia) in detecting A. citrulli, watermelon seed lots with different percentages of artificially infested seed were tested using two different types of sample preparation: seed macerate and seed wash. Using seed macerate, both MC-sELISA and the commercial ELISA kit (Agdia) could detect $A$. citrulli in seed lots with $0.3 \%$ infestation. Compared with bacteria detection in seed macerate, the detection of $A$. citrulli in seed wash gave lower sensitivity and higher background using both methods; 5 and $1 \%$ infestation for MC-sELISA and commercial ELISA, respectively (Fig. 4). Therefore, seed macerate is recommended for preparation of seed extracts before applying MC-sELISA.

To determine the feasibility of this method for screening for $A$. citrulli in naturally infested seed, 10 commercial seed lots were tested using the MC-sELISA, a commercial ELISA kit (Agdia), and SGO. For MC-sELISA and the commercial ELISA test kit, three replicates were performed for each seed sample $(n=400)$. By both methods, A. citrulli was detected in three watermelon seed lots, numbers 1, 2, and 5, (Table 2). The results from MC-sELISA and the commercial ELISA test kit agreed with those from the standard SGO method. For the SGO method, BFB symptoms were observed on seedlings derived from three watermelon seed lots, numbers 1,2 , and 5 , with 16,4 , and $8 \%$ of diseased seedlings, respectively (Table 2 ).

\section{Discussion}

In this study, we generated a specific MAb (MAb 11E5) against A. citrulli and used it to develop sELISA for detection of this pathogen in leaf, fruit, and seed samples. MAb 11E5 reacted with all $A$. citrulli strains tested with no cross-reactivity to other closely related bacteria in the family of Comamonadaceae such as $A$. $\mathrm{fa}$ cilis, $C$. acidovorans, and $C$. testosteronii. The MAb produced in this study has an advantage over the previously reported PAbs $(18,21)$ because of its higher specificity. Additionally, when this MAb is used in ELISA, it can detect a wider range of A. citrulli strains than the MAb-based commercial ELISA kit (Agdia) and MAb-based immunochromatographic strip test (QuickStix; Envirologix).

Generally, A. citrulli strains can be divided into at least two groups (groups I and II) based on pathogenicity assays, DNAfingerprinting profiles, and whole-cell fatty-acid analyses (20). Group I includes strains mainly isolated from non-watermelon cucurbits, while group II includes the typical watermelon BFB- causing strains $(4,20)$. MAb 11E5 strongly reacted with Ac KK9, which is the same strain as Ac 202-69 that belongs to group II (20). However, because reference strains of group I are not available in Thailand because pathogen import is strictly prohibited, we used $A$. citrulli strains isolated from non-watermelon cucurbits (melon, cantaloupe, squash, bottle gourd, and cucumber) in Thailand and found that MAb 11E5 could also react to these strains.

MAb 11E5 could detect $A$. citrulli strains that were isolated from imported squash and bottle gourd seed. Although MAb 11E5 detected all strains of $A$. citrulli tested, the commercial ELISA kit (Agdia) and immunochromatographic strip test (QuickStix; Envirologix) failed to detect squash (SQ) type B strain, which was isolated from squash seed. Strain SQ type B was identified to be $A$. citrulli using carbon-source metabolic fingerprinting (Biolog system) and a PCR method using primers specific to the 16S rRNA gene of A. citrulli (21). A. citrulli strain SQ type B showed BFB symptoms on inoculated watermelon, melon, cucumber, bottle gourd, and squash seedlings ( $\mathrm{P}$. Thummabenjapone, unpublished data).

Because of its specificity to A. citrulli, MAb 11E5 was subsequently used for ELISA development. In the case of A. citrulli

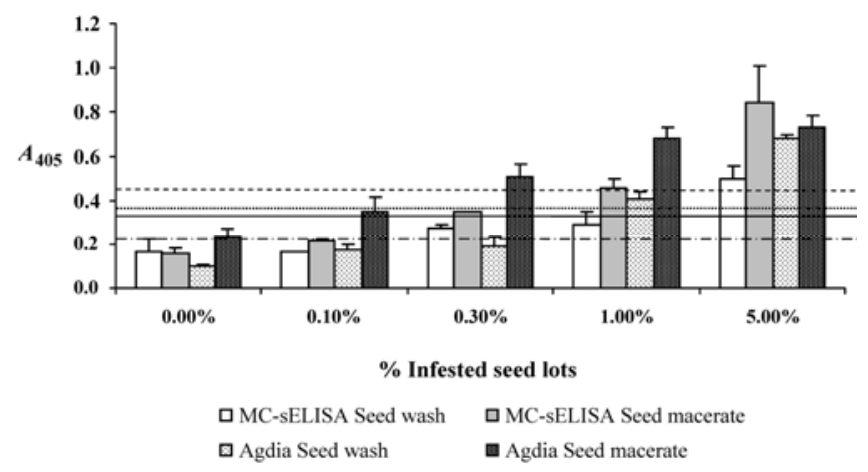

Fig. 4. Detection of Acidovorax citrulli in artificially infested watermelon seed lots by monoclonal antibody captured-sandwich (MC-s) enzyme-linked immunosorbent assay (ELISA) and a commercial ELISA kit (Agdia). Two independent experiments were performed with three replicates per experiment. Data showed an average of the results with error bars representing standard deviation. Cut-off values were twice of values obtained from negative control ( $0 \%$ infested seed lot). For seed wash extraction, the dotted line designates cut-off value for MC-sELISA and the long dashed dot line designates cut-off value for the commercial ELISA kit (Agdia). For seed macerate extraction, the solid line designates cut-off value for MC-sELISA and the dashed line designates cut-off value for the commercial ELISA kit (Agdia).

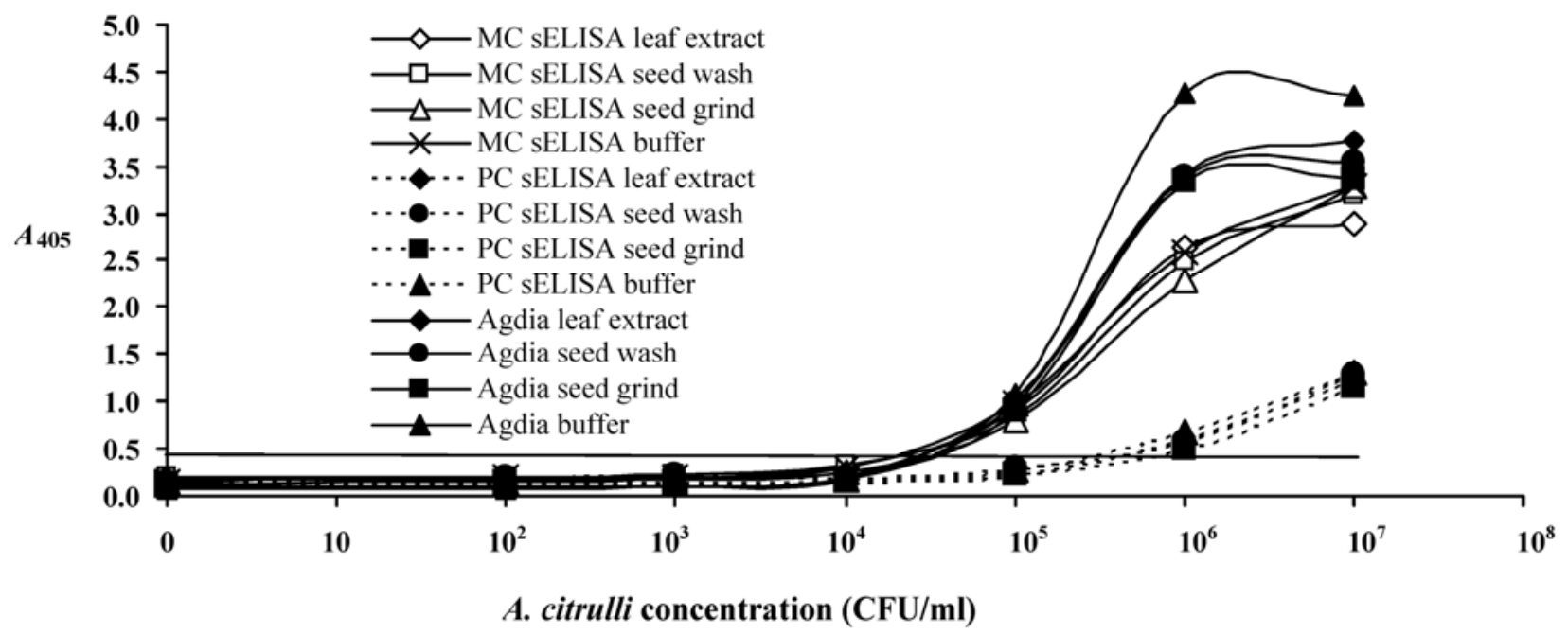

Fig. 3. Comparison of the sensitivity of two sandwich enzyme-linked immunosorbent assay (ELISA) systems-monoclonal antibody captured-sandwich (MC-s)ELISA and polyclonal antibody captured-sandwich (PC-s)ELISA-as well as a commercial ELISA kit (Agdia) for detection of various concentrations of Acidovorax citrulli in extraction buffers, leaf sap, and seed extracts. Two independent experiments were performed with three replicates per experiment. Data showed an average of the results with error bars representing standard deviation. Cut-off values were twice of values obtained from negative control (A. citrulli at $0 \mathrm{CFU} / \mathrm{ml}$ in corresponding sample preparations). Horizontal line designates cut-off values for MC-sELISA, PC-sELISA, and the commercial ELISA kit (Agdia). 
detection, a screening method for field inspection prior to harvest is crucial, and ELISA is the most practical method for this situation. Two sELISA systems were developed and compared for their sensitivity in detection of $A$. citrulli in this study. MC-sELISA was 10 times more sensitive than PC-sELISA in detection of A. citrulli in leaf and seed extracts. The increased sensitivity of MC-sELISA could be explained by the possibility that the PAb, when used as a detecting molecule, could bind to more epitopes on the antigen than the use of MAb that binds a single epitope.

Three extraction buffers were evaluated in this study to reduce nonspecific antibody binding and increase ELISA sensitivity (5). $\mathrm{PVPBST}^{+}$yielded better results than the other two extraction buffers (Tris- $\mathrm{Na}_{2} \mathrm{SO}_{3}$ and PBST) when PAb was used as the detecting antibody in MC-sELISA, whereas Tris- $\mathrm{Na}_{2} \mathrm{SO}_{3}$ and PBST resulted in nonspecific reactions. Without an effective extraction buffer, it is possible that these bacteria were nonspecifically bound to the surface of microtiter plate and subsequently detected by the PAbs. However, $\mathrm{PVPBST}^{+}$extraction buffer contains Tween 20 and egg albumin that can more effectively block nonspecific binding of non-target bacteria to microtiter plate surfaces (17).

It was previously reported that substances in plant and seed extracts interfere with the PCR detection of A. citrulli $(19,20)$. By using MC-sELISA, the effect of an interfering substance was negligible. Comparable sensitivity of detection was observed with the $A$. citrulli-spiked extraction buffer, and the A. citrulli-spiked leaf and seed extracts (A. citrulli at approximately $5 \times 10^{4} \mathrm{CFU} / \mathrm{ml}$ ). It is important to note that seed preparation by grinding yielded higher reactivity than by washing. Previous reports showed that $A$. citrulli is localized on both the surface of the seed coat and the endosperm $(11,19)$, which support our observation that grinding is better for extracting A. citrulli from seed. Therefore, the MC-sELISA is applicable for differentiation between healthy and the artificially infected plant samples. Moreover, MC-sELISA detected A. citrulli in naturally infested leaves and fruit with $100 \%$ correlation with the commercial ELISA kit.

For seed tests, the results obtained with MC-sELISA were completely in agreement with the commercial ELISA kit and SGO but the sensitivity was less than that reported for immunomagnetic separation and PCR $(19,21)$. However, to achieve higher sensitivity, this new MAb against $A$. citrulli can be used with immunomagnetic separation and PCR to improve routine cucurbit seed detection.

In conclusion, the MAb specific to $A$. citrulli has been employed to develop an ELISA test that detected all tested $A$. citrulli strains. The ELISA system can be applied directly to leaf, fruit, and seed samples without pathogen isolation. This simple and inexpensive method can be applicable for routine field disease inspection.

\section{Acknowledgments}

This project was financially supported by National Center for Genetic Engineering and Biotechnology (BIOTEC, Thailand) and Center for Agricultural Biotechnology, Kasetsart University, Kamphaeng Sean Campus/Center of Excellence on Agricultural Biotechnology: (AG-BIO/PERDO-CHE) Thailand. We thank N. Karoonuthaisiri, P. L Watts, and T. Nivitchanyong for their useful comments on this manuscript.

\section{Literature Cited}

1. Alvarez, A. M. 2004. Integrated approaches for detection of plant pathogenic bacteria and diagnosis of bacterial diseases. Annu. Rev. Phytopathol. 42:339-366.

2. Bahar, O., Efrat, M., Hadar, E., Dutta, B., Walcott, R. R., and Burdman, S. 2008. New subspecies-specific polymerase chain reaction-based assay for the detection of Acidovorax avenae subsp. citrulli. Plant Pathol. 57:754763.

3. Bradford, M. M. 1976. A rapid and sensitive method for the quantitation of microgram quantities of protein utilizing the principle of protein-dye binding. Anal. Biochem. 72:248-254.

4. Burdman, S., Kots, N., Kritzman, G., and Kopelowitz, J. 2005. Molecular, physiological, and host-range characterization of Acidovorax avenae subsp. citrulli isolates from watermelon and melon in Israel. Plant Dis. 89:13391347.

5. Jones, J. B., Somodi, G. C., and Scott, J. W. 1997. Increased ELISA sensitivity using a modified extraction buffer for detection of Xanthomonas campestris pv. vesicatoria in leaf tissue. J. Appl. Microbiol. 83:397-401.

6. Kawicha, P., Thummabenjapone, P., and Sirithorn, P. 2002. Genetic diversity within Acidovorax avenae subsp. citrulli in cucurbits production areas of Northeast, Thailand. In: Summary First Int. Conf. Trop. Subtrop. Plant Dis. 125.

7. Kucharek, T., Perez, Y., and Hodge, C. 1993. Transmission of the watermelon fruit blotch bacterium from infected seed to seedlings. (Abstr.) Phytopathology 83:466.

8. Laemmli, U. K. 1970. Cleavage of structural proteins during the assembly of the head of bacteriophage T4. Nature 227:680-685.

9. Latin, R. X., and Hopkins, D. L. 1995. Bacterial fruit blotch of watermelon: the hypothetical exam question becomes reality. Plant Dis. 79:5.

10. Lessl, J. T., Fessehaie, A., and Walcott, R. R. 2007. Colonization of female watermelon blossoms by Acidovorax avenae ssp. citrulli and the relationship between blossom inoculum dosage and seed infestation. J. Phytopathol. 155:114-121.

11. Munkvold, G. P. 2009. Seed pathology progress in academia and industry. Annu. Rev. Phytopathol. 47:285-311.

12. Oi, V. T., and Herzenberg, L. A. 1980. Fusion of NS-1 with immune spleen cells. Pages 357-359 in: Selected Methods in Cellular Immunology. B. B. Mishele and S. M. Shiigi, eds. W. H. Freeman and Company, San Francisco.

13. Rane, K. K., and Latin, R. X. 1992. Bacterial fruit blotch of watermelon: association of the pathogen with seed. Plant Dis. 76:509-512.

14. Rener, J. C., Brown, B. L., and Nardone, R. M. 1985. Cloning hybridoma cells by limiting dilution. Methods Cell Sci. 9:175-177.

15. Schaad, N. W., Postnikova, E., Sechler, A., Claflin, L. E., Vidaver, A. K.,

Table 2. Detection of Acidovorax citrulli in commercial watermelon and cucumber seed lots using seedling grow-out method, monoclonal antibody captured-sandwich enzyme-linked immunosorbent assay (MC-sELISA), and a commercial ELISA kit (Agdia) ${ }^{\mathrm{a}}$

\begin{tabular}{|c|c|c|c|c|c|c|c|}
\hline \multirow[b]{3}{*}{ Seed samples } & \multirow[b]{3}{*}{ Seed $(n)$} & \multicolumn{4}{|c|}{ Seedling grow-out } & & \\
\hline & & \multicolumn{2}{|c|}{ Germination } & \multicolumn{2}{|c|}{ Diseased seedlings } & \multicolumn{2}{|c|}{ Reactivity $\left(A_{405}\right)$} \\
\hline & & Number & Percent & Number & Percent & MC-sELISA & ELISA \\
\hline Watermelon Khonkaen number 1 & 100 & 87 & 87 & 14 & 16 & $2.00 \pm 0.12(+)$ & $2.54 \pm 0.51(+)$ \\
\hline Watermelon Khonkaen number 2 & 100 & 87 & 87 & 3 & 4 & $0.79 \pm 0.07(+)$ & $0.97 \pm 0.03(+)$ \\
\hline Watermelon Khonkaen number 3 & 100 & 76 & 76 & 0 & 0 & $0.12 \pm 0.03(-)$ & $0.09 \pm 0.04(-)$ \\
\hline Watermelon Khonkaen number 4 & 100 & 82 & 82 & 0 & 0 & $0.11 \pm 0.02(-)$ & $0.08 \pm 0.04(-)$ \\
\hline Watermelon Khonkaen number 5 & 100 & 79 & 79 & 6 & 8 & $1.39 \pm 0.43(+)$ & $2.16 \pm 0.44(+)$ \\
\hline Cucumber number 40680101 & 32 & 31 & 97 & 0 & 0 & $0.17 \pm 0.07(-)$ & $0.19 \pm 0.02(-)$ \\
\hline Cucumber number 40680201 & 32 & 27 & 84 & 0 & 0 & $0.21 \pm 0.04(-)$ & $0.12 \pm 0.02(-)$ \\
\hline Cucumber number 40680202 & 32 & 30 & 94 & 0 & 0 & $0.16 \pm 0.01(-)$ & $0.13 \pm 0.02(-)$ \\
\hline Cucumber number 27480301 & 32 & 32 & 100 & 0 & 0 & $0.14 \pm 0.04(-)$ & $0.13 \pm 0.03(-)$ \\
\hline Cucumber number 04380201 & 32 & 26 & 81 & 0 & 0 & $0.22 \pm 0.04(-)$ & $0.13 \pm 0.03(-)$ \\
\hline Healthy watermelon seed & 100 & 98 & 98 & 0 & 0 & $0.16 \pm 0.01(-)$ & $0.12 \pm 0.02(-)$ \\
\hline Healthy cucumber seed & 32 & 31 & 97 & 0 & 0 & $0.13 \pm 0.01(-)$ & $0.19 \pm 0.02(-)$ \\
\hline Seed from $A$. citrulli-infected watermelon & 200 & 176 & 88 & 23 & 13 & $0.85 \pm 0.04(+)$ & $1.26 \pm 0.12(+)$ \\
\hline Seed from A. citrulli-infected cucumber & 32 & 30 & 94 & 6 & 20 & $0.58 \pm 0.01(+)$ & $0.58 \pm 0.06(+)$ \\
\hline
\end{tabular}

${ }^{a}$ Number of seed sampling for MC-sELISA and commercial ELISA, $n=400$. The samplings were done in three replicates. Commercial ELISA kit was purchased from Agdia (ELISA kit, catalog number SRA 14800). Data shown represent the average of absorbance value $\left(A_{405}\right)$ from three replicates. Samples with $A_{405}$ greater than twice of those from the healthy seed were considered positive. 
Jones, J. B., Agarkova, I., Ignatov, A., Dickstein, E., and Ramundo, B. A. 2008. Reclassification of subspecies of Acidovorax avenae as A. avenae (Manns 1905) emend., A. cattleyae (Pavarino, 1911) comb. nov., A. citrulli Schaad et al., 1978) comb. nov., and proposal of A. oryzae sp. nov. Syst. Appl. Microbiol. 31:434-446.

16. Schaad, N. W., Sowell, G., Jr., Goth, R. W., Colwell, R. R., and Webb, R. E. 1978. Pseudomonas pseudoalcaligenes subsp. citrulli subsp. nov. International J. Syst. Bacteriol. 28:117-125.

17. Steinitz, M. 2000. Quantitation of the blocking effect of Tween 20 and bovine serum albumin in ELISA microwells. Anal. Biochem. 282:232238 .

18. Thonmo, Y., and Thummabenjapone, P. 2006. Polyclonal antiserum for Acidovorax avenae subsp. citrulli. Agric. Sci. J. 37 (Suppl.):117-120.

19. Walcott R. R., Castro, A. C., Fessehaie A., and Ling, K. 2006. Progress towards a commercial PCR-based seed assay for Acidovorax avenae subsp. citrulli. Seed Sci. Technol. 34:101-116.

20. Walcott, R. R., Fessehaie, A., and Castro, A. C. 2004. Differences in pathogenicity between two genetically distinct groups of Acidovorax avenae subsp. citrulli on cucurbit hosts. J. Phytopathol. 152:277-285.

21. Walcott, R. R., and Gitaitis, R. D. 2000. Detection of Acidovorax avenae subsp. citrulli in watermelon seed using immunomagnetic separation and the polymerase chain reaction. Plant Dis. 84:470-474.

22. Wang Xiao, Z. L., Xu, F.-S., Zhao, L.-H., and Xie, G.-L. 2007. Immunocapture PCR method for detecting Acidovorax avenae subsp. citrulli from watermelon. Chin. J. Agric. Biotechnol. 4:173-179.

23. Willems, A., Goor, M., Thielemans, S., Gillis, M., Kersters, K., and De Ley, J. 1992. Transfer of several phytopathogenic Pseudomonas species to Acidovorax as Acidovorax avenae subsp. avenae subsp. nov., comb. nov., Acidovorax avenae subsp. citrulli, Acidovorax avenae subsp. cattleyae, and Acidovorax konjaci. Int. J. Syst. Bacteriol. 42:107-119. 